\title{
ReAding Tutor, A Reading SuPPort System FOR JAPANESE LANGUAGE LEARNERS
}

\author{
Yoshiko KAWAMURA* \\ Tokyo International University \\ kawamura@tiu.ac.jp
}

\begin{abstract}
The present paper gives an overview of the tools and materials included in the Japanese language reading tutorial system Reading Tutor and the multilingual lexicographical project Reading Tutor Web Dictionary. This is followed by a discussion of possible uses of Reading Tutor and the Web Dictionary in Japanese language instruction and for supporting autonomous language learning. The paper further presents one particular use of these tools and resources in the development of learning material for foreign candidates taking the Japanese national examination for certifying care workers. We conclude with suggestions for effective guidance in fostering autonomous vocabulary learning.
\end{abstract}

\section{Keywords}

reading support; multilingual dictionary; autonomous learning; language for special purposes; language learning support tools

\section{Izvleček}

Članek predstavlja orodja in gradiva $\mathrm{v}$ sistemu za podporo branju v japonščini Reading Tutor in v večjezičnem slovarskem projektu Reading Tutor Web Dictionary ter njihovo možno uporabo tako za poučevanje japonščine kot tudi za podporo samostojnemu jezikovnemu učenju. Nadalje predstavlja konkreten primer uporabe teh orodij in virov za izdelavo učnega gradiva za tuje kandidate, ki se pripravljajo na japonski državni izpit za zdravstvene delavce. V zaključku predlaga nekaj pedagoških pristopov za učinkovito podporo samostojnemu učenju besedišča.

\section{Ključne besede}

bralna podpora; večjezični slovar; samostojno učenje; jezik stroke; orodja za podporo jezikovnemu učenju

\footnotetext{
* Translated by Kristina Hmeljak Sangawa
} 


\section{Introduction}

The Japanese language reading tutorial system Reading Tutor has been used in many ways by Japanese learners and teachers around the world since its appearance on the web in 1999. It has been accessed more than 2 million times since its inception, and it is presently being accessed 1500 times a day on average. In 2003 a companion project was launched to add multiple languages to the Reading Tutor dictionary tools. This paper is organised in the following way. Section 2 describes the reading support system Reading Tutor, section 3 proposes ways in which this tool can be used to foster autonomous learning, and section 4 presents the multilingual lexicographical project Reading Tutor Web Dictionary and its possible uses In section 5, we present a case study of the use of these resources for the development of learning materials for foreign candidates taking the Japanese national examination for certified care workers, and section 6 concludes with suggestions for effective guidance and learner support geared at fostering autonomous vocabulary learning in the age of the internet.

\section{The Japanese language reading tutorial system Reading Tutor}

Reading Tutor (http://language.tiu.ac.jp/) is an Internet site combining reading materials and various tools to support reading and learning Japanese as a second language. As seen in Table 1, the uses of Reading Tutor are graphically displayed on the front page of this site. Reading Tutor is freely available online and can be accessed and used any time from anywhere in the world.

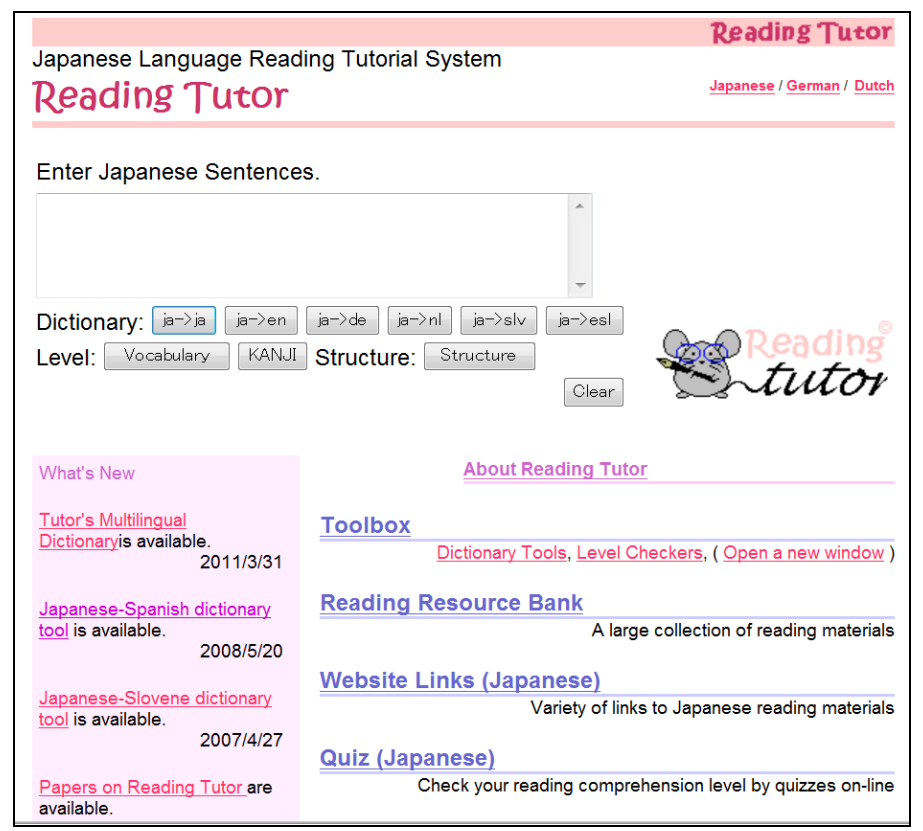

Figure 1: Reading Tutor's top page 
Reading Tutor includes the following tools and resources which were developed to support Japanese language reading and learning. In order to use the tools, users input (type or paste) text into the upper box, and click on the button of the tool they wish to use.

\subsection{Dictionary tool}

The following dictionaries are available, as can be seen from the button acronyms: a monolingual dictionary with Japanese definitions of the Japanese headwords ( $j a->j a)$, a Japanese-English (ja->en), Japanese-German (ja->de), Japanese-Dutch (ja->nl), Japanese-Slovene (ja->slv) and a Japanese-Spanish (ja->esl) dictionary. This tool links all words appearing in the input text to the chosen dictionary and displays the text alongside dictionary information on a new page. When the user clicks any word to look up dictionary information, relevant dictionary information appears on the right side, and clicked words appear at the bottom of the left frame, enabling the user to save a list of unknown words for later revision.

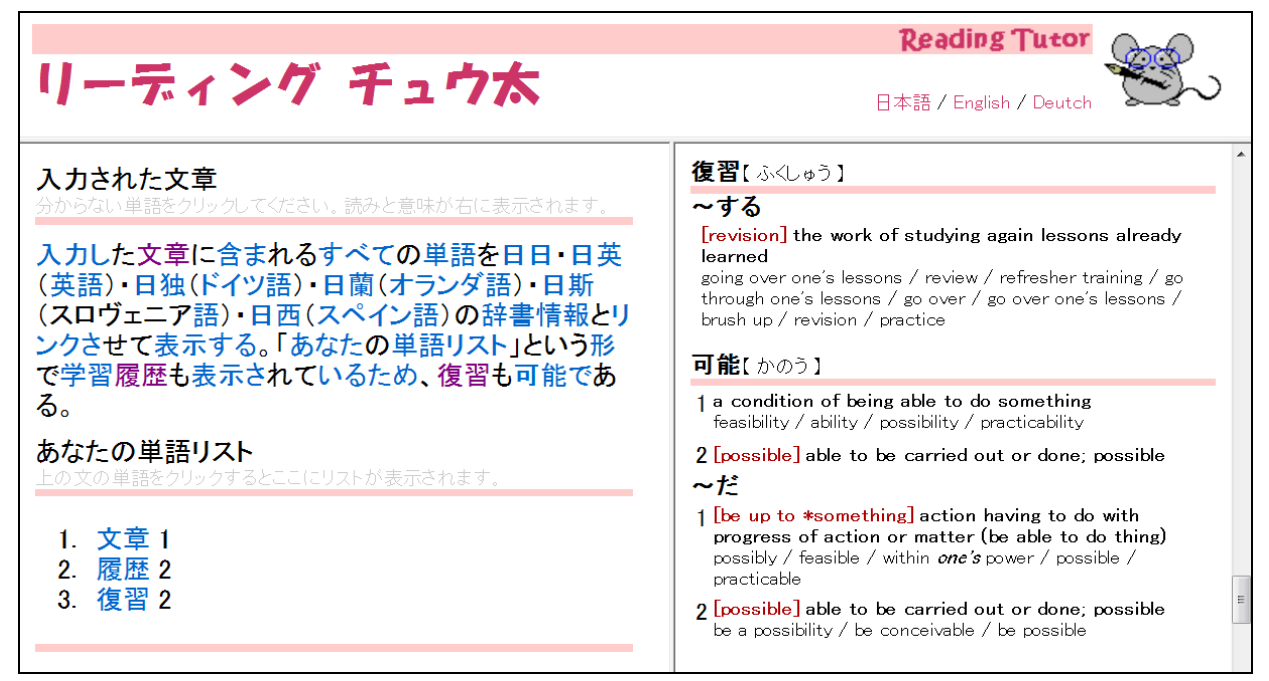

Figure 2: Reading Tutor dictionary tool output window

Figure 2 shows an example of the dictionary tool's output, where the user has selected the Japanese-English dictionary and clicked once on the word 文章 and twice each on the words 履歴 and 復習. The last clicked word is shown at the top of the right-hand frame.

\subsection{Level Checker (Vocabulary Checker and Character Checker)}

These two tools analyse the text, determine the difficulty level of each word or each character in the text according to the old version of the Japanese Language 
Proficiency Test Content Specifications (JF \& AIEJ, 2002; hereafter abbreviated to JLPT), and display the text showing words or characters in the colour of the JLPT level they belong to, alongside a list of all words or characters appearing in the text, divided by JLPT levels, as displayed in Figure 3 (see next section).

\subsection{Grammatical patterns tool}

This tool automatically detects grammatical patterns and functional words in the text, links them to (a part of) information in the dictionary of grammatical patterns Nihongo bunkei ziten [日本語文型辞典] (Group JAMASII, 1998) and displays them in a layout similar to the dictionary tool. The tool can be accessed by pressing the button [structure]. The site also offers the reading resources listed below.

\subsection{Reading resource bank}

This repository contains reading material that can be immediately used for studying Japanese either in class or for self-study. Each text is marked for level of difficulty, calculated according to the vocabulary it contains, making it easy to choose the material that is most appropriate for the reader.

\subsection{Collection of website links}

The link page presents carefully selected sites that may be useful to learners of Japanese as a second language grouped by subject into news, Japanese culture, Japanese language learning and Japanese language teaching.

\subsection{Grammar quiz}

The site includes grammar questions at levels 1 and 2 of JLPT, where users can check their own grammatical competence. This section includes both an automatic answer checker and grammar explanations.

Tools and materials which make up Reading Tutor thus serve different purposes and can be useful both for Japanese language instruction and for supporting autonomous learning, as explained in detail in Tutor's introductory manual (Kawamura, 2009). 


\section{Editing teaching materials using Reading Tutor}

\subsection{Verifying learners' proficiency level}

By combining material from the Reading Resources Bank with the Vocabulary Checker, teachers can easily gauge their students' level. When learners read a passage and click on unknown words to check the reading or meaning, these words are recorded in a section named "Your word list". Teachers can then retrieve this list, feed it into the Vocabulary Checker, and find the JLPT level the unknown words belong to. The same process can be used for any other reading material not included in the Reading Resources Bank, simply by inputting the text into the dictionary tool first and then using it as reading material. One advantage of this process is that it allows students to check their own level objectively.

\subsection{Developing reading materials appropriate for the students' level}

The Vocabulary Checker can also be used to develop reading materials which are appropriate to the students' level. When the user inputs a text into the Vocabulary Checker, the text is processed and appears as in Figure 3 below, with each word in the text colour-coded for its level in JLPT. The text in Figure 3 is an example of a processed text, containing the entry 雷 [kaminari - "thunder"] from the site Key Aspects of Japan (Sugiura \& Gillespie, 2012).

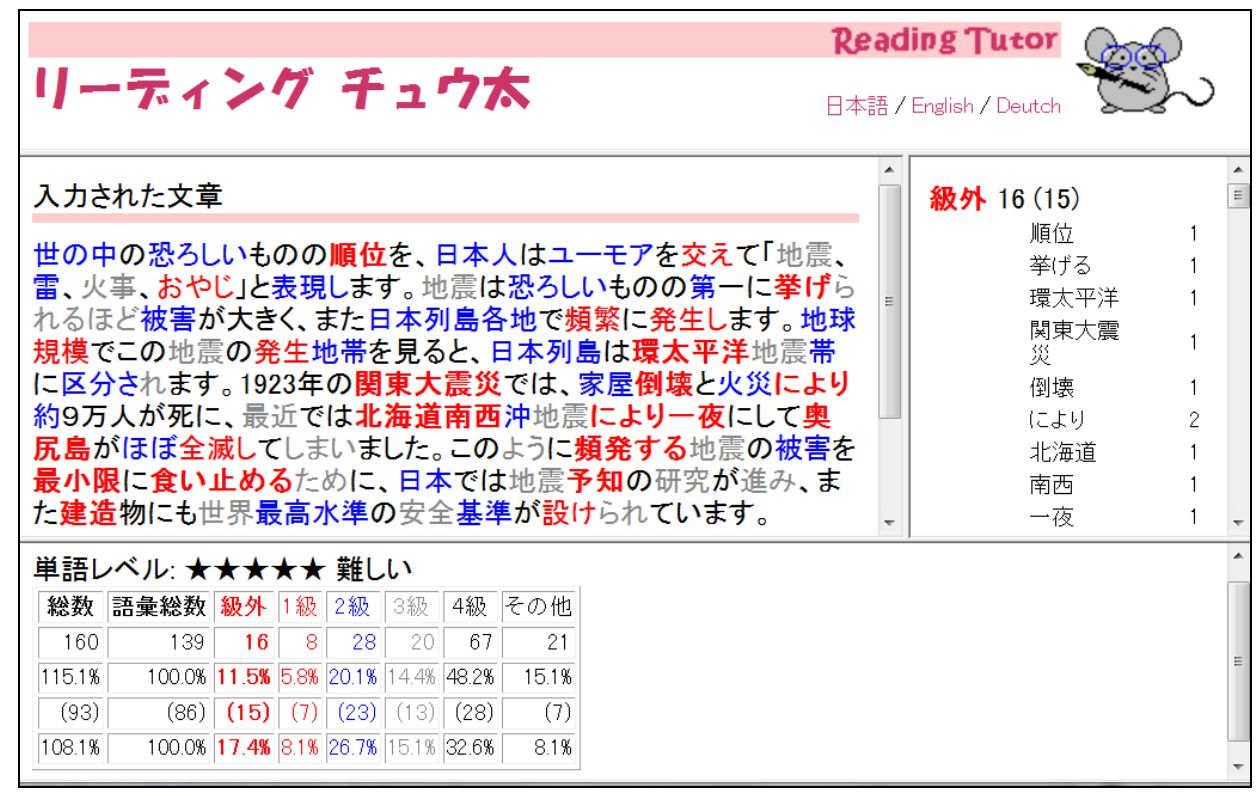

Figure 3: Output of Reading Tutor Vocabulary Level Checker 
As can be seen in Figure 3 all words in the processed text are colour-coded according to their level in JLPT: level 4 words (the easiest) are displayed in black, level 3 (upper beginners) in grey, level 2 (intermediate) in blue, level 1 (advanced) in red, and words which are not included in the JLPT are displayed in bold red characters. Teachers can thus read through the colour-coded text and rewrite the parts not appropriate to the students' level. For example, if a teacher is preparing reading material for intermediate students, the words in red could be rewritten. This process can be then repeated with the rewritten text to check for any remaining difficult words, thus ensuring the text has been edited appropriately for the level of the students.

\subsection{Developing supplementary learning materials}

Reading materials for language courses are usually accompanied by supplementary material such as word lists, comprehension questions, cloze tests, grammar tests, Chinese character tests, texts with phonetic guides (also called furigana, text in smaller type added above or below Chinese characters to show pronunciation), and other types of material. Some of these materials - word lists, Chinese character quizzes, phonetic guides - can be easily prepared using the tools offered on the Reading Tutor web site.

a) Word lists: To prepare a word list for a reading passage, teachers can feed the passage into the Vocabulary Checker and obtain a list of all words contained. If needed, they can then feed this list into one of the dictionary tools to obtain a list of words with their readings and translations.

b) Kanji quiz: The colour-coded output of the Vocabulary Checker can be used to prepare kanji quizzes. The colour-coded text may be useful in helping student visually grasp their reading level.

c) Text with phonetic guides: A text with phonetic guides can easily be edited using the furigana function of the Reading Tutor Web Dictionary, as explained in section 4. A text with phonetic guides can be used as preparation for a kanji quiz, for practicing reading aloud and other exercises.

\subsection{Integrating autonomous learning into reading classes}

Reading classes can be conducted more effectively by combining them with autonomous learning, individual preparation and review. This is especially effective in classes of students with very different proficiency levels, or mixed classes with students from countries using kanji script and those where kanji is not used. If the text to be studied is made available on the web, students can prepare and review their reading using the dictionary tool. They can also use these tools to prepare for writing or reading aloud tests. However, they should be warned that all tools use an automatic parser and that errors may occur. 


\section{The multilingual Japanese dictionary Reading Tutor Web Dictionary}

To answer the demand for different dictionaries from learners of Japanese around the world, a project for the creation of a multilingual dictionary was started in 2003 . The result of this project is offered online as the Reading Tutor Web Dictionary1. In this project, a monolingual dictionary of Japanese headwords with Japanese definitions and examples is being translated into more than 20 languages by dictionary teams around the world. Each entry is made available online as soon as it is edited by the editing team. The compilation of the Japanese-Russian and Japanese-Vietnamese dictionaries have been completed for words in the JLPT.

The Reading Tutor Web Dictionary includes a tool for analysing any input and glossing it with entries from any of the dictionaries it includes, a tool for adding phonetic guides (furigana) above all Chinese characters, and an example search tool.

All tools can be accessed from the Reading Tutor Web Dictionary top page, as shown in Figure 4.

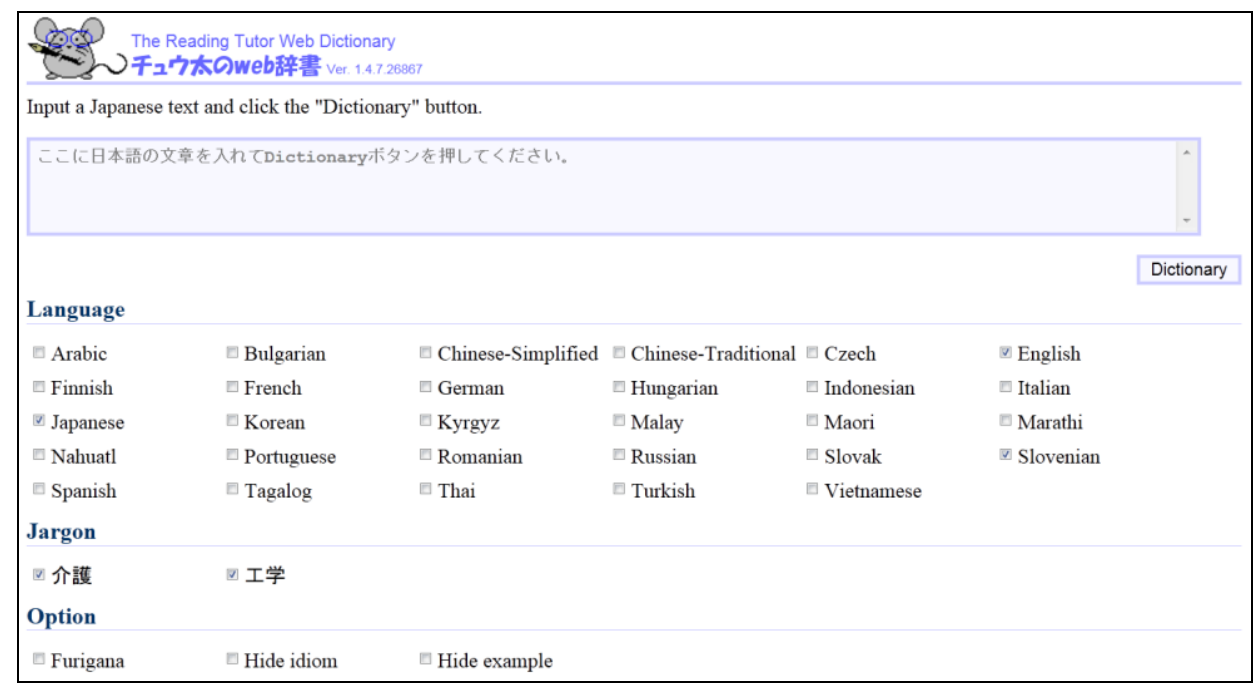

Figure 4: The Reading Tutor Web Dictionary top page

The tools on this page can be used in the same way as Reading Tutor. When a user types or pastes any text into the text box at the top of the page, and presses the Dictionary button, the text is automatically analysed and glossed with entries from the selected dictionary or dictionaries. By default, the dictionary of the language set as the preferred language in the user's web browser is automatically selected. In addition, the user can choose to add any number of dictionaries by ticking the boxes in the dictionary list below the text box. For example, by ticking the boxes next to the words

\footnotetext{
${ }^{1}$ http://chuta.jp/
} 
Japanese, English and Slovenian, as in Figure 4 above, the user obtains glosses from the Japanese-Japanese, Japanese-English and Japanese-Slovenian dictionaries at the same time, as shown in Figure 5.

\begin{tabular}{|c|c|}
\hline 入力された文章 & $\begin{array}{l}\text { 越える【こえる】 } \\
\text { 超える【こえる】 }\end{array}$ \\
\hline \multirow{6}{*}{ 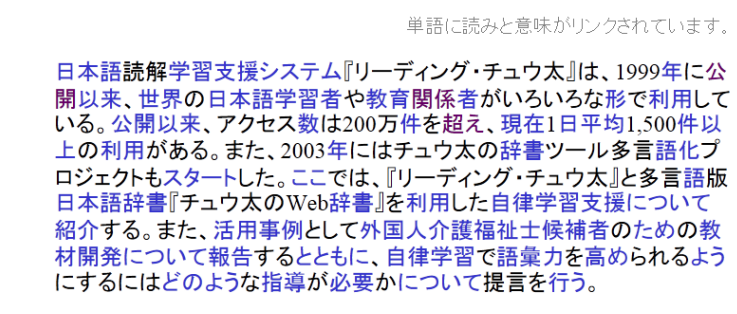 } & $\begin{array}{l}\text { 越える } \\
\text { to get over/to cross }\end{array}$ \\
\hline & \\
\hline & 超える** \\
\hline & $\begin{array}{l}\text { [動詞自竍 } \\
1 \text { 基準より多くなる }\end{array}$ \\
\hline & $\begin{array}{l}\text { [prekoračiti] nekaj postane več kot normalno } \\
\text { presegati, prekašati, biti več kot }\end{array}$ \\
\hline & $\begin{array}{l}\text { [们饺 } \\
10 万 人 \text { 超える入場者があった。 }\end{array}$ \\
\hline あなたの単語リスト & $\begin{array}{l}\text { Obiskovalcev je bilo več kot } 100 \text { tisoč } \\
\text { 2自分の考え万や立場からさらに前へ進む; }\end{array}$ \\
\hline \multirow{3}{*}{$\begin{array}{l}\text { 公開1回 } \\
\text { 関係1回 } \\
\text { 超える1回 }\end{array}$} & 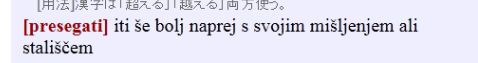 \\
\hline & biti nad čem, iti nad kaj \\
\hline & $\begin{array}{l}\text { 想像を超える } \\
\text { presegati vse predstave }\end{array}$ \\
\hline Chuta Dictionary Project & $\begin{array}{l}\text { 理解を招える } \\
\text { presegati razumevanje }\end{array}$ \\
\hline & 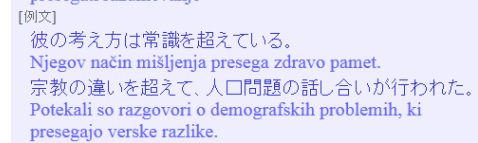 \\
\hline
\end{tabular}

Figure 5. Reading Tutor Web Dictionary's text output

Figure 5 shows the output obtained by inputting the Japanese version of this paper's first paragraph into the Reading Tutor Web Dictionary and selecting Japanese, English and Slovene. Each word in the processed text in the left frame is linked to the dictionary entries listed in the right frame. When the user clicks on any of the linked words on the left, the corresponding dictionary entry in the frame on the right side automatically scrolls up and appears at the top of the right hand frame. At the same time, the same word appears in the bottom part of the left frame, under the heading $あ$ なたの単語リスト [anata no tango risuto] ("Your word list"). Figure 5 is a picture of the user's monitor after the user has clicked on the words 公開 [kōkai “opening”], 関係 [kankei "relationship"] and 超える [koeru "to get over"]; the last word clicked is displayed at the top of the right hand frame. As can be seen in this screenshot, each meaning described and translated in the dictionary entry is also accompanied by examples, so that users can check not only the meaning or translation of each word, but also its typical usage. The dictionary entry for the verb koeru has been completed in the Japanese-Slovenian dictionary and is therefore displayed with examples and their Slovenian translations.

In the case of English, Korean, Chinese, Indonesian and Tagalog, all entries of the JLPT word list have been translated into these languages in the form of a minidictionary where entries have only the word's translation equivalents without examples, so that even for entries of the main multilingual dictionary where the 
examples have not been edited yet, the word's translations appear in the glossary. In the Figure 5 example, entries from the Japanese-English mini-dictionary appear in the right frame.

All words listed under "Your word list" are linked to the glossary on the right, so that users can easily review them after reading.

Examples in the dictionary entries are also preprocessed, so that the user only needs to click on any example to see it with a glossary of all the words it contains on its right side.

The furigana function can be used by ticking the "Furigana" checkbox at the bottom of the Reading Tutor Web Dictionary top page. If the checkbox is ticked, the output in the left frame is displayed with phonetic guides above each word, as can be seen in Figure 6.

\begin{tabular}{|c|c|}
\hline 入力された文章 & \begin{tabular}{|l|} 
越える【こえる】 \\
超える【こえi \\
【える】
\end{tabular} \\
\hline 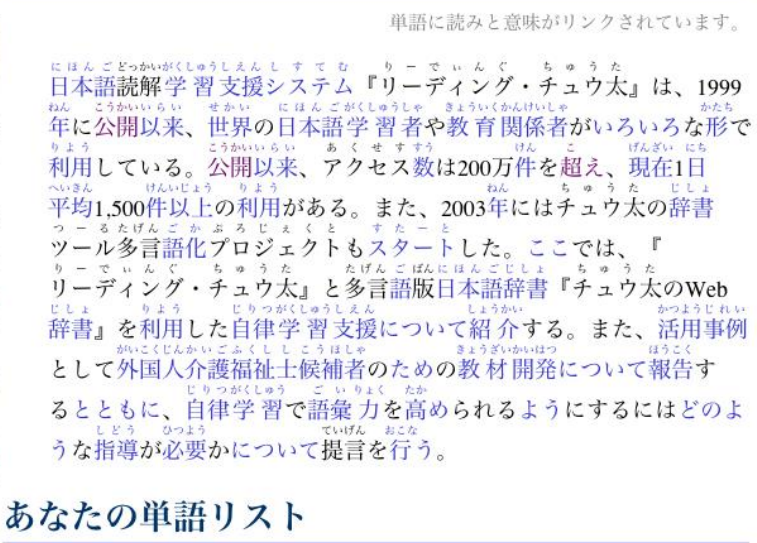 & 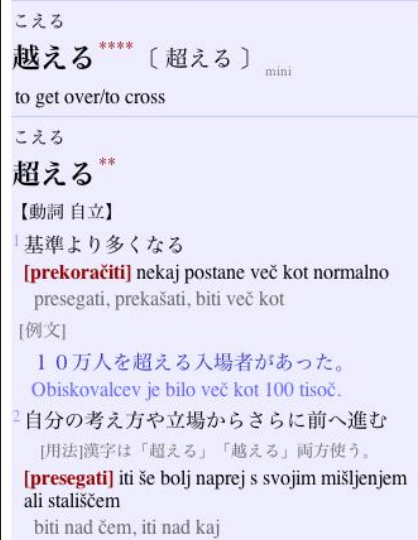 \\
\hline
\end{tabular}

Figure 6: Reading Tutor Web Dictionary's text output with phonetic guides (furigana)

\subsection{Example search, fuzzy searches}

Users can also search for single dictionary entries and examples using the "Word / Example Sentence Search" box at the bottom of the web dictionary top page, as shown below in Figure 7. Here it is possible to use the special character * (an asterisk) for fuzzy searches. When the user inputs a word without any special characters, the system displays the entry of the headword that exactly matches the word. By adding an asterisk to the end of a character string in the search box, the user can find entries for all headwords beginning with that character string (for example, しか* returns しかし, しかた etc.), and by adding an asterisk to the beginning of the word, find all headwords ending with that string (for example, *出す returns 出す, but also 思い出 す, 言い出す, 飛び出す etc.). 
Moreover, by adding an asterisk to both sides of the search string, the user can see all occurrences of that string both within headwords and in the examples, thus finding words that are present in the examples, even if they are not yet included as dictionary entries.

\begin{tabular}{|c|c|c|c|}
\hline \multicolumn{4}{|c|}{ Word / Example Sentence Search } \\
\hline *としで & Japanese & V & Search \\
\hline
\end{tabular}

Figure 7: Word/Example sentence search box on Reading Tutor Web Dictionary's top page

In Figure 7, the string として [toshite "as"] is enclosed in asterisks to search for all examples containing this character strings. Figure 8 below shows the result of this search.

\section{Examples}

処ぶりに会った姪っ子は、ほっべが赫丸々としていてかわいらかった。(かわいらしい）

吉野山は接の名所として名高い(名高い)

それは社会人としてはずかいい行為です。(肬ずかいい)

細、枝は切り落としてください。(細い)

ここで、アルバイトとして皿洗、老しているのは、彼の仮の姿だ。国入帰机ば、ホテルの経営者なのだ。(仮)

小ネジをどしかに落としてしまった。(小)

この授業では主として日本の古典文学を扱います。(主)

映画の助監督は監督の助手として、スケジュールの作成、役者の手配などの仕事をします。(助)

彼はグループの長としての青任がある。(長)

父は別として、家族はみんな朝じ飯を食べる。(別)

Figure 8: Part of the output obtained by searching for *として*using the Word/Example sentence search tool

Examples containing the search string are displayed as shown above, followed by the headword they belong to, in brackets. If the Japanese part of the entry has been translated into other languages, these translations can be displayed by clicking on the headword shown within brackets.

This tool retrieves all matches for any character string, without further linguistic analysis. As can be seen in Figure 8, searching for the string toshite, which means "as is" if used by itself, results in an output screen also containing examples where toshite is part of another word, such as otoshite ("dropping"). Finding all occurrences of the string toshite used as a compound particle can be a useful exercise in reading. Such a list can also be used in class, for an exercise in distinguishing different uses of a word or pattern. 


\section{Case study: Using Reading Tutor's tools to develop learning materials for foreign candidates to the Japanese national examination for certified care workers}

This section presents a case study in which the Reading Tutor tools were used to develop learning materials to support autonomous study. From 2009 to 2011, a set of learning materials was developed to help foreign candidates studying for the Japanese national examination for care workers. These learners are prospective health care workers who have come from Indonesia and the Philippines to Japan on the basis of Japan's Economic Partnership Agreements with these countries. These candidates are expected to pass the Japanese national examination for certified care workers within 4 years of their arrival to Japan, while working as trainees in hospitals or other institutions. They are only allowed to take the examination once. They usually come to Japan with little or no knowledge of the Japanese language, but cannot afford to spend much time in language classes because of their full time employment as nursing trainees. We therefore decided to develop learning materials to support autonomous study, using Reading Tutor's tools to develop a vocabulary list, a character list and a dictionary of nursing terminology (Kawamura \& Nomura, 2010, Kawamura et al., 2011)

\subsection{Construction of a dictionary of nursing terminology}

As a preliminary step in the development of learning materials, we surveyed the vocabulary used in past national examinations for care workers, using the Vocabulary Checker. As a result of this survey, the examination questions were found to include 3799 words not listed in the JLPT vocabulary list. We then compiled a JapaneseIndonesian-Tagalog-English glossary of all words in the JLPT and of all words appearing at least twice in the past examination questions surveyed. Each Japanese headword in the glossary usually has one translated equivalent for each language, but the dictionary editing system also allows for more than one translation to be added to each word. The glossary was incorporated into the Reading Tutor Web Dictionary, making it immediately available to foreign candidates of the Japanese national examination for care workers.

\subsection{Development of an instructional vocabulary list for candidates to the national examination for care workers}

In order to compile an instructional vocabulary list to help candidates to the national examination for care workers, vocabulary frequently appearing in the examination was surveyed using Vocabulary Checker.

All vocabulary used in the 16 national examinations from the 3 rd to the 18 th was surveyed, and 1146 words were found to appear at least 16 times in these examinations. By excluding vocabulary of level 3 and 4 (the easiest) of the Japanese 
Language Proficiency Test, we obtained a list of 808 words, which we named the "808 Nursing Wordlist" (介護単語 808 [Kaigo tango 808]).

\begin{tabular}{|c|c|c|c|c|c|c|c|}
\hline & 見出し語 & 読み & 品詞 & やさしい日本語 & 英語 & インドネシア語 & メモ \\
\hline$\square \square$ & 愛 & あい & 名詞 & 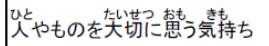 & love/affection & cinta/mencintai & \\
\hline$\square \square$ & 相手 & あいて & 名詞 & 荷かを一籍にするんと & partner/opponent & pasangan/lawan & \\
\hline$\square \square$ & 明らか & あきらか & な形 & はっきりしている & clear & terang & \\
\hline$\square \square$ & \begin{tabular}{|l} 
預かる//預 \\
けるる
\end{tabular} & $\begin{array}{l}\text { あずかる//あ } \\
\text { ずける }\end{array}$ & 動詞 & 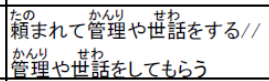 & $\begin{array}{l}\text { to keep//to leave sth } \\
\text { with sb }\end{array}$ & $\begin{array}{l}\text { dititipi } \\
\text { (titipan)//menitipkan }\end{array}$ & \\
\hline$\square \square$ & アセスメント & あせすめんと & 名詞 & 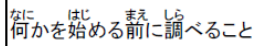 & assessment & penilaian & \\
\hline$\square \square$ & 与える & あたえる & 動詞 & あげる & to give & memberikan & \\
\hline$\square \square$ & 〜当たり & あたり & 接尾 & 〜にどれだけあるか & per & per/setiap & \\
\hline$\square \square$ & 悪化 (する) & あっか & 動詞 & 㤎くなる(こと) & $\begin{array}{l}\text { degeneration/getting } \\
\text { worse }\end{array}$ & memburuk & \\
\hline
\end{tabular}

Figure 9: Sample of the “808 Nursing Wordlist” (介護単語 808 [Kaigo tango 808]) for candidates to the national examination for care workers

As can be seen in Figure 9, each entry in the 808 Nursing Wordlist is composed of a Japanese headword, its reading (in hiragana), a definition in simple Japanese, and one or more English and Indonesian equivalents. The Japanese explanations use words from the high frequency level words of Japanese.. The English and Indonesian equivalents were compiled using the Reading Tutor Web Dictionary. A column with checkboxes was added on the left side for learners to be able to monitor their own progress.

\subsection{Compilation of supplementary material to support autonomous learning}

Since candidates to the national examination for care workers come from linguistic backgrounds where Chinese characters are not used, the large number of characters to be newly learned is a serious problem. This needs to be taken into consideration when planning efficient ways to learn the nursing terminology included in the 808 word list described above. We therefore compiled a supplementary set of learning materials aimed at mastering Chinese characters, the "Nursing Character List" (介護漢字 [Kaigo kanji]). An excerpt from this list is shown in Figure 10. 


\begin{tabular}{|c|c|c|c|c|c|c|c|}
\hline & 漢字·単語 & 読み & 品詞 & やさしい日本語 & 英語 & インドネシア語 & xモ \\
\hline$\square$ & 定 & さだめる·テイ & 動詞 & 決める & to decide & dapat menetapkan & \\
\hline$\square$ & 定める & さだめる & 動詞 & 湇める & to decide/to appoint & dapat menetapkan & \\
\hline$\square$ & 定期 & ていき & 名詞 & 诀まった期箱 & regular & periodik & \\
\hline$\square$ & 定年 & ていねん & 名詞 & 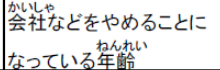 & retiring age & usia pensiun & \\
\hline$\square$ & 指定（する） & してい & 動詞 & 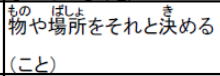 & appointment/to appoint & penunjukan & \\
\hline$\square$ & 設定（する) & せってい & 動詞 & 洼める(こと) & setup/to set up & penetapan/menetapkan & \\
\hline$\square$ & 測定（する） & そくてい & 動詞 & 測る(こと) & $\begin{array}{l}\text { measurement/to } \\
\text { measure }\end{array}$ & ketetapan & \\
\hline$\square$ & 特定（する) & とくてい & 動詞 & それだと浐める(こと) & $\begin{array}{l}\text { identification/specific/to } \\
\text { identify }\end{array}$ & spesifik & \\
\hline
\end{tabular}

Figure 10: Sample of the "Nursing Character List" (介護漢字 [Kaigo kanji]) for candidates to the national examination for care workers

In order to compile this material, the 808 Nursing Wordlist was fed into the Kanji Checker and all characters used in the 808 Nursing Wordlist were ranked and listed according to frequency, beginning with the most frequent character. As can be seen in Figure 10, each character is listed in a highlighted (grey) line containing its possible readings, the part of speech of the word the character represents when used by itself, an explanation of its meaning in simple Japanese, translations into English and Indonesian, and some space for user's notes. This line with basic information about a single character is followed by all 808 Nursing Wordlist entries which include the character. These words are arranged according to the position of the character in the word, in order to help users focus their attention on word formation and to strengthen their ability to infer a word's meaning from the characters in the compound. Words which begin with the headword character are displayed first, followed by words ending with the character, and finally by all other words containing the character.

The structure of the entries, showing the part of speech of the word represented by a character when used by itself and in a list of compound words ordered by the location of the character within the word, is conducive to a better understanding of word formation and word networks, as can be seen in the following examples.

Verb-like characters in compound words are often accompanied by characters for the verb's object on their right side, or characters for verb modifiers on their left side. For example, when the character 定, which can be used to represent the root of the verb sadameru [定める “to decide"], is used in the first part of a compound word, such as in teiki [定期 “fixed period, fixed term”], teinen [定年 “retirement age”], the second part of the compound word usually refers to the object of this verb (in the case of 定 sadameru - "to decide, to fix", the second character in the compound refers to what is being decided or fixed: - $k i$ 期 “period”, -nen 年 “year, age”). On the other hand, when the character is used as the last part of a compound word, such as in shitei [指定 
“indicate" + “decide" $\rightarrow$ “designate, specify, appoint”], settei [設定 “provide, prepare" + "decide" $\rightarrow$ "establish, set up"], sokutei [測定 “measure, fathom" + "decide" $\rightarrow$ "measure"], tokutei [特定 “special” + "measure" $\rightarrow$ "specify"], the first part of the compound word refers to the manner in which the action described by the verb is carried out (in the above cases, the first character in the compound refers to how something is being decided).

Noun-like characters in compound words can act as modifiers to the following characters when appearing at the beginning of a compound, or can be modified by the characters preceding them when appearing at the end of a compound. For example, when the character 人, which can be used to represent the word hito [人 "person"], is used as the first part of a compound word, such as in jinsei [人生 "person" + "life" $\rightarrow$ "human life"], jinkou [人工 "person" + "construction" $\rightarrow$ "man-made, artificial"], the prefix $人$ modifies the following morpheme, meaning "of man", "human". On the other hand, when the character is used as the last part of a compound word, such as in kojin [ 個人 "single" + "person" $\rightarrow$ "individual"], roujin [老人 “old" + "person" $\rightarrow$ "old person"], the morpheme written with this character (jin) is modified by the first part of the compound word, meaning "some kind of person".

The Nursing Character List also includes an explanation on how Chinese character compounds are formed. Vocabulary learning can be easier when the mechanisms for composing Chinese character compounds is understood. By observing these rules, learners acquire the ability to guess the meaning of unknown compounds, which may lead to better reading proficiency.

The 808 Nursing Wordlist and the Nursing Characters List are available for download at http://chuta.jp/Archivel, for learners anywhere.

\subsection{Building a workbook with controlled vocabulary for the national examination for care workers}

The following guidelines were followed to develop a workbook for the national examination for care workers.

a. vocabulary is limited to JLPT level 3 and 4 and the 808 Nursing Wordlist;

b. expressions not included in these lists are only used when they are deemed too important to be reworded using controlled vocabulary, and are explained in notes;

c. words related to Japanese culture or systems are also explained in notes;

d. explanations in notes are written using basic vocabulary and words in the 808 Nursing Wordlist;

e. sentences are as short as possible; bulleted lists are also used if necessary.

Learning materials for beginning students are usually compiled with simplified vocabulary, but considering that the materials are meant to prepare students for the 
state examination, we decided that words frequently appearing in the examination should not be rewritten using simpler expressions, and therefore adopted the guidelines outlined above.

To aid the editing team in compiling the workbooks according to the above guidelines, we needed a tool that would enable editors to check immediately whether the explanations and exercises they were writing contained any vocabulary outside the scope of the selected wordlists. By using the Vocabulary Checker within the Reading Tutor site (section 2.2), we developed a tool which we named "Nursing wordlist Checker" and have made it publicly available at (http://basil.is.konanu.ac.jp/chuta/level/).

The Nursing wordlist Checker analyses any input text using the morphological analyser MeCab (Kudo, 2006), splits the text into words, checks it against the wordlists mentioned above and shows the same text with each word coloured using the following colour scheme:

- black: basic words (included in JLPT level 3 and level 4) and function words;

- green: words in the 808 Nursing Wordlist;

- blue: words from JLPT level 2 which are not included in the 808 Nursing Wordlist;

- $\quad$ red: all other words.

Editors used this tool while compiling the workbooks to check whether the words they were using were included in the specified vocabulary lists. When a keyword they needed to use was not included in the lists, they added a gloss which explains its meaning with words from the list. All words from the 808 Nursing Wordlist which appeared in the text are marked with bold typeface, so that learners can easily discern important words and will find their explanation in the accompanying 808 Nursing Wordlist. All texts in the workbooks are marked with furigana (pronunciation guides), so that learners can easily find them in the Reading Tutor Web Dictionary.

These were the guidelines and tools used to compile five workbooks in simplified Japanese to support autonomous learning for the new curriculum of the Japanese national examination for care workers (Kawamura, 2011). While the above paragraphs describes a case study used to develop learning materials for prospective care workers, the same procedure could also be used to develop materials for other specialised areas.

\section{Japanese teaching in the age of the internet}

With the spread of the internet, learners of Japanese around the globe can now access diverse information about and in Japanese, without restrictions on time and place. At the same time, the motives of learners approaching Japanese are also diversifying. In parallel with these changes, the modes of Japanese language education 
also need to change from textbook-centered classroom teaching, to a mode of language education which is conducive to autonomous learning. In this context, three approaches are crucial in supporting autonomous learning: 1) reading instruction which includes both speed-reading and intensive reading; 2) vocabulary training concentrating on word usage; and 3) character training which fosters the ability to infer the meaning of unknown words and characters. Let us consider each one in turn.

\subsection{Reading instruction including both fast and intensive reading}

Learners need to develop the ability to skim or scan written documents in order to find only the necessary information within a long text. At the same time, when they find a stretch of text with the information they are looking for, they need to be able to understand it accurately. With the explosion of information available now, it has become even more important to train learners to read both fast and accurately.

\subsection{Vocabulary training concentrating on word usage}

Each word in a language refers to meaning which expands in multiple directions, but the semantic features of words are different in each language. Vocabulary and reading instruction therefore needs to guide learners to notice not only idioms and fixed expressions, but also the semantic area covered by each word. One way of achieving this is by using a dictionary. For example, using the Reading Tutor Web Dictionary, where different meanings and usages of each word are described, translated and exemplified, learners can appreciate the different ways in which each word can be used by trying to translate each example into their mother tongue. Such an activity can help them realise the need to understand words in context, and thus contribute to their linguistic awareness.

\subsection{Character training fosters the ability to infer the meaning of unknown words and characters}

The number of words and characters learners must memorise when learning Japanese, especially for those coming from non-kanji backgrounds, is daunting. As described in section 5, learners need instruction regarding compound formation for words of Chinese origin. A sound knowledge of the basic rules by which such words are formed can help learners enhance their ability to guess the meaning of unknown words. Trying to infer the meaning of a new word both from its context and also by analysing the characters with which it is composed and their position within the word, before looking it up in a dictionary, may help learners deepen their vocabulary knowledge over time.

The three approaches outlined above aim at fostering autonomous learning. In this age when information in and regarding Japanese can be accessed online from anywhere in the world, Japanese language education can greatly profit from the advantages of the 
Internet. We hope that some of new modes of instruction introduced here will foster learners' independence and help them advance steadily and efficiently in their learning efforts.

\section{Acknowledgments}

The present paper is a revised and extended version of presentations delivered at The University of Tsukuba, Japan Women's University, The Korean Association of Japanese Language Teaching, and The Institute of East Asian Studies at Thammasat University. The development of learning support tools and learning materials described in this paper was made possible by the collaboration of HOBARA Rei (The University of Tokyo), KITAMURA Tatsuya (Konan University) and all the members of the Reading Tutor project team. I would like to extend my sincere thanks to all of them.

\section{References}

Group JAMASII [グループ・ジャマシイ] (Eds.) (1998). Nihongo bunkei ziten [日本語文型 辞典]. Tokyo: Kurosio Publishers [くろしお出版].

Japan Foundation [国際交流基金], \& Association of International Education, Japan [日本国際 教育協会]. (2002). Nihongo nōryoku shiken Shutsudai kijun (kaiteiban) [日本語能力試験 出題基準【改訂版】] - Japanese Language Proficiency Test: Test Content Specifications (Revised Edition). Tokyo: Bonjinsha [凡人社].

Kawamura, Y. [川村よし子] (2009). Chūta no tora no maki --- Nihongo kyōiku no tame no intānetto katsuyōjutsu [チュウ太の虎の巻一日本語教育のためのインターネット活用 術] (“Practical uses of the internet for Japanese language education”). Tokyo: Kurosio [ くろしお出版].

Kawamura, Y. [川村よし子], \& Nomura, A. [野村愛] (2010). Kaigo no tame no mini jisho o kumiireta jisho tsūru no kaihatsu [介護のためのミニ辞書を組み入れた辞書ツールの 開発] (“Development of a dictionary tool including a mini-dictionary for health work"). Nihongo kyōiku hōhō kenkyūkaishi - Japanese Language Education Methods [日本語教育 方法研究会誌], 17 (1), 22-23.

Kawamura, Y. [川村よし子], Nomura, A. [野村愛], Natō, A. [名藤杏子], Kaneniwa, K. [金庭 久美子], Saiki, M. [斉木美紀], Kitamura, T. [北村達也] (2011). Kaigo fukushishi kōhosei no tame no kokka shiken ni muketa kyōzai no kaihatsu [介護福祉士候補生のた めの国家試験に向けた教材の開発]. In Nihon kyōiku kōgaku gakkai 27 kai zenkoku taikai kōen ronbunshū [日本教育工学会第 27 回全国大会講演論文集], 625-626.

Kawamura, Y. [村よし子] ed. (2011). Yasashii nihongoban kaigo fukushishi shin curriculum gakushū workbook [やさしい日本語版 介護福祉士新カリキュラム学習ワーク ブック], 5 vols., Shizuoka: Shizuoka Prefecture [静岡県].

Kudō, T. [工藤拓]. (2012). MeCab : Yet Another Part-of-Speech and Morphological Analyzer, Retrieved from: http://mecab.sourceforge.net/.

Sugiura, Y. [杉浦洋一], \& Gillespie, J.K. (2012). Key Aspects of Japan - Nichi-ei taiyaku Nihon bunka kiiwaado jiten [日英対訳日本文化キーワード事典]. Retrieved from: http://www.japanlink.co.jp/ka/. 
